\title{
Scanning Electron Microscopic Study of Slime Formations in a Water Injection Station of Oil India Limited in Assam, India
}

\author{
Ranjan K. Bhagobaty*, S. Purohit, M. C. Nihalani \\ R\&D Department, Oil India Limited, Duliajan 786602, India
}

*Correspondence to:
Bhagobaty RK,
Tel: +91-374-2806332
Fax: +91-374-2800522
E-mail: ranjan_bhagobaty@oilindia.in

Received September 21, 2015

Revised December 7, 2015

Accepted December 8, 2015

\begin{abstract}
Microorganisms specifically groups of bacteria exhibiting physiological activities of production of acids are a major cause of concern because of their ability to induce corrosion in oil field pipelines and metal systems involved in water handling. Water Injection Stations as a means of secondary recovery from existing oil producing reservoirs, are often employed in most upstream oil and gas industries to ensure replenishment of voidage, maintenance of reservoir pressure and optimization of crude emulsion throughput. In the present study, scanning electron microscopy of macroscopic orange coloured slime formations sampled from leaking valves on the flow-lines of a Water Injection Stations of Oil India Limited revealed the presence of filamentous bacterial mats in association with diatoms. The species composition of the acidic slime formations from the sampled locations reveal the possible role of acid producing iron oxidizing bacteria (IOB) like Acidithiobacillus ferrooxidans in association with Gomphonema sp. in creating conditions for bio-corrosion.
\end{abstract}

Key Words: Water Injection Stations, Macroscopic slime formations, Bacterial mats, Diatoms, Bio-Corrosion

\section{INTRODUCTION}

Microorganisms that inhabit the most extreme acidic niches on our planet are highly diverse in terms of their physiologies and phylogenetic relationships (Hallberg \& Johnson, 2001; Baker \& Banfield, 2003). Bacteria are known to produce conspicuous biofilms or macroscopic structures such as streamers, snottites and microbial stalactites. Electron Microscopic examination of these macroscopic structures which are commonly encountered in acidic environments (Johnson, 2009), reveal that extracellular polymeric substances (EPS) produced by the bacterial cells are responsible for the phenomenon (Johnson et al., 2014). Industrial process water is not sterile, so there is biofilm in all water handling systems. However, problems occur when the biofilm builds up ("biofouling"), creating dead biomass and therefore a nutrient source that leads to re-growth of organisms in the water. Slime-forming acid producing bacteria grow in a patchy distribution over the metal surface and exclude oxygen via respiration; the slime impedes oxygen diffusion, creating an oxygen concentration cell. This ultimately leads to the subsequent macro-fouling of the system (visualized as orange coloured slime) and concomitant enhancement of microbially induced corrosion. Although the economic implications of bio-fouling in industrial water systems are high the phenomenon is often overlooked by corrosion engineers who often fail to accept, recognize and mitigate the problem (Coetser \& Cloete, 2005). Macroscopic microbial growth that appear as gelatinous orange coloured slime in acidic metalrich environments have been reported to be composed of mixed bacterial communities of iron- and sulphur-oxidizing acidophiles. Acidophilic microorganisms primarily bacteria play a major role in enhanced bio-corrosion of the pipelines and metal systems involved in oil field water handling systems. In addition, water injection systems of upstream oil and gas industries infested heavily with bacteria also experience a drastic loss of injectivity, formation damage and filter plugging (Penkala et al., 2002). Scanning electron microscopy

(a) This is an open-access article distributed under the terms of the Creative Commons Attribution Non-Commercial License (http://creativecommons.org/licenses/by-nc/4.0) which permits unrestricted noncommercial use, distribution, and reproduction in any medium, provided the original work is properly cited.

Copyrights (c) 2015 by Korean Society of Microscopy 
(SEM) is used extensively to study the ultrastructure and morphological features of biological samples (Kim, 2012). The present investigation therefore aimed to ascertain the role of microorganisms in the formation of macroscopic acid slime in metal surfaces of leaking valves on the injection-lines using SEM.

\section{MATERIALS AND METHODS}

\section{Description of Study Site}

Water injection as secondary recovery scheme for the Nahorkatia oil field of Oil India Limited located in the NorthEastern state of Assam in India, was commenced in the year 1966. Water is taken out from deep tube wells from a depth of 100 to $120 \mathrm{~m}$ and sent to Water Injection Stations at a surface pressure of 6 to $8 \mathrm{~kg} / \mathrm{cm}^{2}$. Eight water injection pumps are being used to boost injection water pressure to around $125 \mathrm{~kg} / \mathrm{cm}^{2}$ and after boosting the water is, injected to nine water injection wells at depths of about approximately 2,700 $\mathrm{m}$, through two different discharge manifolds. All the water injection lines are 4 inch carbon steel.

\section{Sample Collection}

Macroscopic slime and water samples in replicates of three, were collected from two identified locations namely Source Well Manifold and Deep Tube Well NBS (DTW NBS) (Fig. $1,2)$ in the Water Injection Stations under study in sterile glass containers as per the guidelines given in NACE Standard TM0194-2004 (field monitoring of bacterial growth in oil and gas systems). The water samples for iron test were collected carefully and acidulated using hydrochloric acid (to $\mathrm{pH} 4 \sim 5)$ to avoid precipitation of $\mathrm{Fe}(\mathrm{OH})_{3}$ and $\mathrm{Fe}_{2} \mathrm{O}_{3}$ during

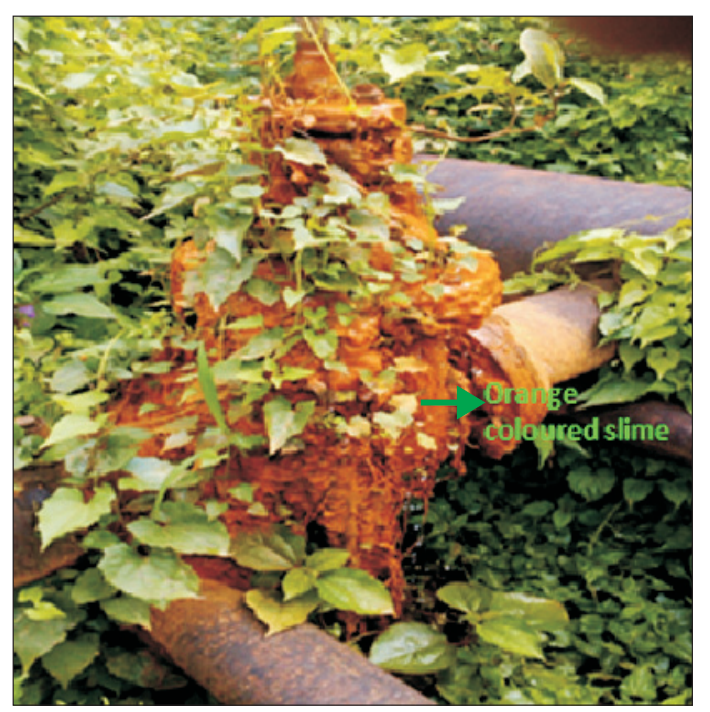

Fig. 1. Macroscopic orange coloured (acidic) slime formation in a leaking valve of water flow line in Source Well Manifold. transportation to laboratory. The Iron content as $\mathrm{Fe}^{2+}$ (in ppm) was determined calorimetrically by using iron test kit containing thioglycolic acid and ammonium thioglycolate (MColortest; Merck KGaA, Germany) in a Shimadzu UVVis spectrophotometer (UV-1700, software: UV probe version 2.31; Shimadzu, Japan). $\mathrm{P}^{\mathrm{H}}$ of the water samples was measured using a calibrated Hanna HI $2215 \mathrm{P}^{\mathrm{H}}$ meter (Hanna Instruments, USA).

\section{Scanning Electron Microscopy of Slime Samples}

Each of the replicate samples collected from the sampling locations were prepared by making thin sections with a sharp knife from which $5 \times 10 \mathrm{~mm}$ sections were attached to a 15 mm specimen stub using a carbon tape. The sample was the air-dried in ambient conditions. The samples were then sputter coated with gold in a SEM coating system SC 502 (Bio-Rad, USA). SEM S-3600N (Hitachi High-Technologies Corporation, Japan) was used to analyze the specimens, using a secondary electron detector and an accelerating voltage of $15 \mathrm{kV}$. Images were captured with scan speed of $80 / 100$ seconds $(50 / 60 \mathrm{~Hz})$. A total of ten SEM micrographs for each sample were generated at varying magnifications for image analysis and microorganism identification.

The SEM micrographs included the images of the macroscopic slime formations at the two sampling locations were compared with available web based resources (classification databases with images and previous scientific reports) like DIATOMS of the United States (http://westerndiatoms. colorado.edu/about), The ANSP Algae Image Database (https://diatom.ansp.org/algae_image/), European Diatom Database (http://craticula.ncl.ac.uk/Eddi/jsp/index.jsp), The Automatic Diatom Identification And Classification

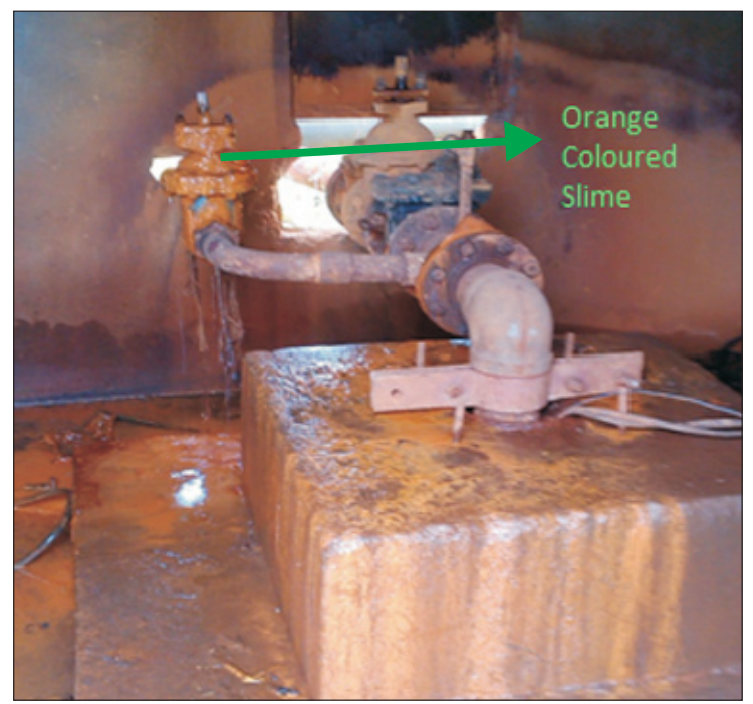

Fig. 2. Macroscopic orange coloured (acidic) slime formation in water flow line of Deep Tube Well NBS. 
Table 1. Sample characteristics and summary of inferences

\begin{tabular}{ccccc}
\hline $\begin{array}{c}\text { Sample } \\
\text { No. }\end{array}$ & Description & $\mathrm{pH}$ & $\begin{array}{c}\text { Iron content of water from } \\
\text { the sampling point (ppm) }\end{array}$ & $\begin{array}{c}\text { Species composition of } \\
\text { biofilm }\end{array}$ \\
\hline 1 & Orange coloured slime (Source Well Manifold) & 2.8 & 6 & Acidithiobacillus ferrooxidans and Gomphonema sp. \\
2 & Orange coloured slime (Deep Tube Well NBS) & 3.0 & 7 & Acidithiobacillus ferrooxidans and Gomphonema sp. \\
\hline
\end{tabular}

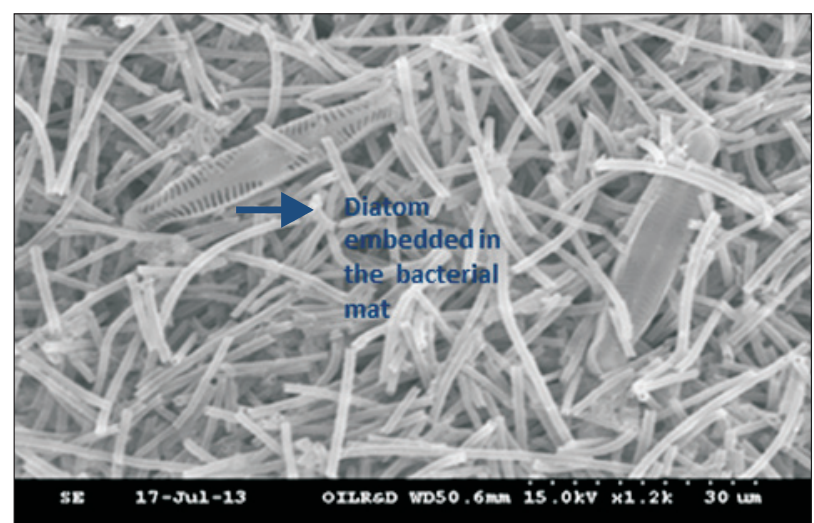

Fig. 3. Scanning electron microscopy micrograph of orange coloured (acidic) slime formation sample (Source Well Manifold).

(ADIAC) Diatom Image Database (http://rbg-web2.rbge. org.uk/ADIAC/db/adiacdb.htm), The Prokaryotes (eds by Gu JD and Mitchell R (ISBN: 978-3-642-31330-1), Description of Acidithiobacillus ferrooxidans in Microbewiki (http://microbewiki.kenyon.edu/index.php/Thiobacillus), Description of Iron Bacteria (https://pl.wikipedia.org/wiki/ Bakterie_\%C5\%BCelazowe) to arrive upon the most probable species identities for the bacterial and diatom species.

\section{RESULTS}

The macroscopic acid slime formations in both the sampling locations are shown in Fig. 1 and 2. SEM micrographs of gelatinous orange coloured slime sampled from the leaking valves of flowlines at both the sampling locations i.e., a Source Well Manifold and DTW NBS, shows the presence of cylindrical rod like structures that appear to be filamentous bacterial mats. These bacterial biofilms are seen to be interspersed with structures typical of diatoms (Fig. 3-5).

Table 1 summarizes the inferences from the SEM micrographs for both the sampling locations where the probable identity of the microbial species involved in the formation of macroscopic orange coloured acid slime formations is suggested.

\section{DISCUSSION}

The pattern of the microbial mats in both the sampling locations as visualized in the SEM micrographs are similar, with the likelihood of the presence of only a single morphotype of

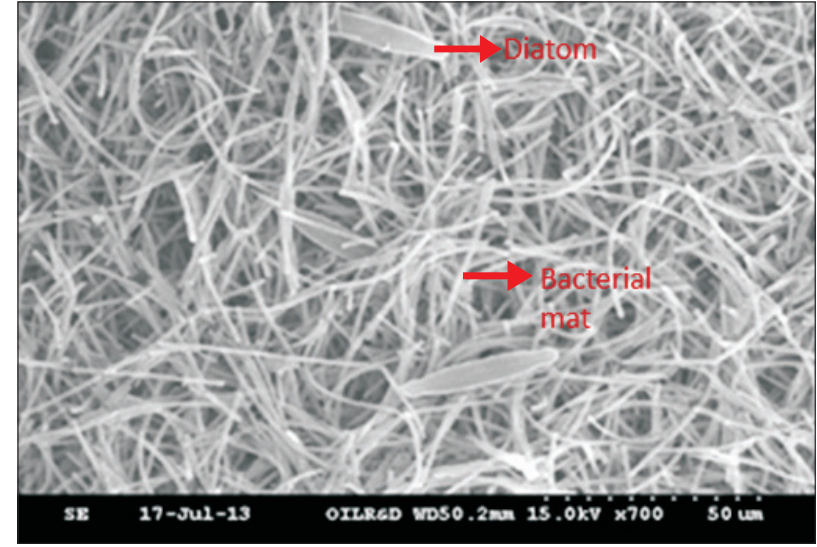

Fig. 4. Scanning electron microscopy micrograph of orange coloured (acidic) slime formation sample (Deep Tube Well NBS).

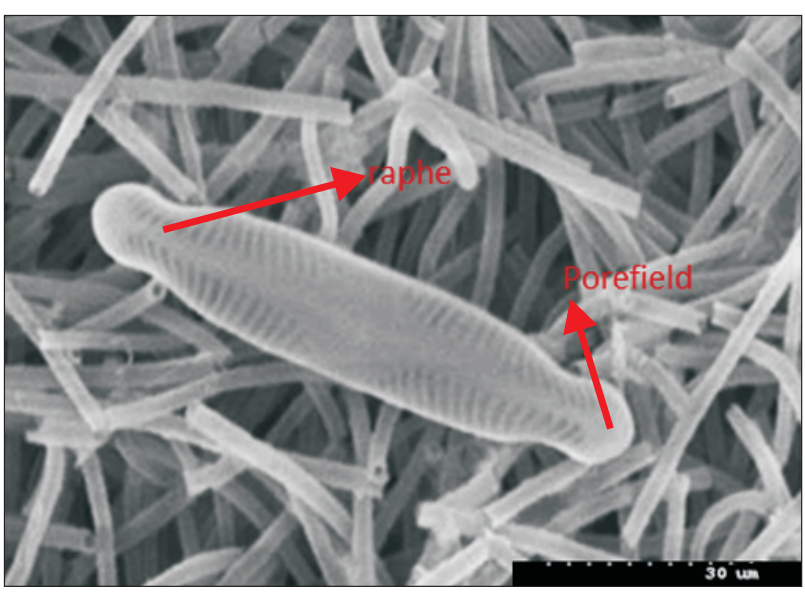

Fig. 5. Diatom species involved in the biofilm formation.

bacteria (cylindrical rod like filaments) and diatom species in both the cases (Fig. 3 and 4). Similar observations about the limited biodiversity of the microbial communities of the streamers have been made by Hallberg and his co-workers in 2006, while studying the macroscopic streamer growths in acidic and metal-rich mine waters in North Wales (Hallberg et al., 2006). Further they reported that all of the iron-oxidizing autotrophic bacterial isolates from the two sampling sites under study i.e., an abandoned copper mine and a chalybeate spa were isolates of $A$. ferrooxidans rather than commonly encountered Leptospirillum spp. Wakao et al. (1985) isolated only iron and sulphur oxidizing bacteria from acid streamers 
draining an iron sulfide mine in Japan ( $\mathrm{pH} 1.8 \sim 2.2)$ and concluded that the streamers were composed (predominantly) of the chemolithotroph $A$. ferrooxidans, which was embedded in a gelatinous matrix.

The results clearly reveal the microbial origin of the macroscopic orange coloured acidic slime formations where biofilms of filamentous aerobic acid producing iron oxidizing bacteria (IOB) (A. ferrooxidans) that are able to utilize the oxidized iron available in the water can be visualized. Acid producing bacteria were also detected in high numbers in the water samples collected from the flow lines of both the locations where the acid slime formations were observed (data not shown). Ferrous iron-oxidizing filamentous bacterial isolates have been reported to form macroscopic slime (streamer-like growths) in laboratory conditions also (Johnson et al., 1992). The presence of diatoms (Fig. 5, Table 1) with the bacterial species in the biofilms is interesting as diatoms are now known to contribute to biocorrosion in association with acidophilic bacteria (Landoulsi et al., 2011). Cooksey (1981) while studying the adhesion of a fouling diatom to glass observed that the primary biofilm is generally dominated by bacteria, whereas the first major accumulation of biomass is attributed to diatoms. The adhesion of diatoms on metal surfaces itself is related with the secretion of mucilaginous material (EPS) (Hoagland et al., 1993). Diatom EPS which are mostly carbohydrate-based polymers with some protein content, provides diatoms with the ability to bind to both hydrophilic and hydrophobic substrata (Landoulsi et al., 2011). Gomphonema sp. have been reported from urban wetlands in India (Alakananda et al., 2013) and have been reported as the dominant biofouling diatom species on stainless steel surface biofilms after immersion in natural waters (Andrewartha et al., 2010). Recently, Yang et al. (2015) while studying the seasonal variations in fouling diatom communities on the Yantai coast of China also reported Gomphonema sp. to be one of the dominant biofouling diatom communities that developed on glass slides immersed in seawater.

\section{CONCLUSIONS}

The present investigation successfully establishes the microbial origin of the macroscopic acid slime formations in the leaking valves on the flow-lines of a Water Injection Stations of Oil India Limited. The presence of diatoms in association with acid producing iron bacterial biofilms as revealed by the SEM micrographs indicate that a symbiotic relationship exists between the constituent microflora of these macroscopic slime formations for creating conditions for bio-corrosion. Currently research is undergoing to ascertain the identity of the microorganisms with molecular biological tools and in studying their role in enhancing bio-corrosion.

\section{CONFLICT OF INTEREST}

No potential conflict of interest relevant to this article was reported.

\section{ACKNOWLEDGMENTS}

Authors are thankful to Management of Oil India Limited for allowing this work to be published.

\section{REFERENCES}

Alakananda B, Mahesh M K, and Ramachandra T V (2013) Role of environmental variables in diatom distribution in urban wetlands of Peninsular India. DIATOM: J. Jpn. Soc. Diatomol. 29, 3-12.

Andrewartha J, Perkins K, Sargison J, Osborn J, Walker G, Henderson A, and Hallegraeff G (2010) Drag force and surface roughness measurements on freshwater biofouled surfaces. Biofouling 26, 487496.

Baker B J and Banfield J F (2003) Microbial communities in acid mine drainage. FEMS Microbiol. Ecol. 44, 139-152.

Coetser S E and Cloete T E (2005) Biofouling and biocorrosion in industrial water systems. Crit. Rev. Microbiol. 31, 213-232.

Cooksey K E (1981) Requirement for calcium in adhesion of a fouling diatom to glass. Appl. Environ. Microbiol. 4, 1378-1382.

Hallberg K B, Coupland K, Kimura S, and Johnson D B (2006) Macroscopic streamer growths in acidic, metal-rich mine waters in north Wales consist of novel and remarkably simple bacterial communities. Appl. Environ. Microbiol. 72, 2022-2030.
Hallberg K B and Johnson D B (2001) Biodiversity of acidophilic prokaryotes. Adv. Appl. Microbiol. 49, 37-84.

Hoagland K D, Rosowski J R, Gretz M R, and Roemer S C (1993) Diatom extracellular polymeric substances: function, fine structure, chemistry and physiology. J. Phycol. 29, 537-566.

Johnson D B (2009) Extremophiles: acid environments. In: Encyclopaedia of Microbiology, ed. Schaechter M, pp. 107-126, (Elsevier, Oxford).

Johnson D B, Ghauri M A, and Said M F (1992) Isolation and characterization of an acidophilic, heterotrophic bacterium capable of oxidizing ferrous iron. Appl. Environ. Microbiol. 58, 1423-1428.

Johnson D B, Hallberg K B, and Hedrich S (2014) Uncovering a microbial enigma: isolation and characterization of the streamer-generating, iron-oxidizing, acidophilic bacterium "Ferrovum myxofaciens". Appl. Environ. Microbiol. 80, 672-680.

Kim I (2012) Epidermal features of the Nelumbo nucifera tissues and Lotus effect. Korean J. Microscopy 42, 95-103. 
Landoulsi J, Cooksey K E, and Dupres V (2011) Review--interactions between diatoms and stainless steel: focus on biofouling and biocorrosion. Biofouling 27, 1105-1124.

Penkala J E, Salma T, Nelman-Gonzalez M, Sams C F, and Harless M L (2002) Implications of bacterial loading on water quality in oilfield systems. NACE International [Internet]. Available from: http://www. onepetro.org/mslib/servlet/onepetropreview?id=NACE-02035. Accessed 2014 Nov 2.
Wakao N, Tachibana H, Tanaka Y, Sakurai Y, and Shiota H (1985) Morphological and physiological characteristics of streamers in acid mine drainage water from a pyritic mine. J. Gen. Appl. Microbiol. 31, 17-28.

Yang C, Wang J, Yu Y, Liu S, and Xia C ( 2015) Seasonal variations in fouling diatom communities on the Yantai coast. Chin. J. Oceanol. Limnol. 33, 439-446. 